\title{
Relationships of Behavioral, Cognitive, and Decisional Control in Self Control of Deaf Student
}

\author{
${ }^{1}$ Istiqomah Putri Mirasandi, ${ }^{2}$ Abdul Salim, ${ }^{3}$ Muhammad Akhyar, ${ }^{4}$ Herry Widyastono \\ 1,2,3,4 Magister of Special Education, Sebelas Maret University, Surakarta, Central Java, Indonesia
}

\begin{abstract}
This study aims to determine the relationship between behavioral control, cognitive control, and decisional control in self-control in children with hearing impairments. The sample of this research is the students of Junior High School and Senior High School in Special School X Surakarta section of Hearing Impairment, totaling 30 students. Data collection techniques in this study using questionnaire instrument in the form of Likert scale. This research uses quantitative research method with descriptive statistical analysis. The results showed that children's self-control with hearing impairments was highest in the aspect of decisional control, then behavioral control, and the lowest was cognitive control.
\end{abstract}

Keywords: Relationship, Self Control, Student with Hearing Impairment

\section{Introduction}

Self-control is needed in interacting with others in order to behave in a good social manner (Hijriah, 2014). Good self-control is needed to control emotions in regulating their behavior so as not to behave negatively. Humans should be aware that excessive emotion or actions that only promote emotions can be harmful to think logically and not useful for themselves or others (Riswandi, 2015). In an individual's life, an individual is required to consistently cultivate himself. Therefore, in order to fulfill the desire of the individual must control his behavior so as not to disturb the comfort of others and not doing things that deviate. Selfcontrol is concerned with how an individual controls the impulses from within (Hurlock, 1990).

Self-control is the ability of individuals to adjust their behavior to what society considers socially acceptable (Papalia, 2004). Self-control is an ability possessed by an individual in the sensitivity of reading his or her situation and environment. In addition, the ability to control and manage behavioral factors in accordance with situations and conditions to

\footnotetext{
* Corresponding author: Istiqomah Putri Mirasandi istiqomah.pm@gmail.com

Published online at http://IJDS.ub.ac.id/

Copyright @ 2019PSLD UB Publishing. All Rights Reserved
}

present themselves in the socialization of the ability to control behavior, the tendency to attract attention, the desire to change the behavior to be suitable for others, pleasing others, always confirm with people others, and mask his feelings (Gufron \& Rinawati, 2011, p.22).

Self-control influenced by several factors, namely internal factors (from individual self) and external factors (individual environment) (Gufron \& Risnawati, 2011, p.32). Here are the factors that affect selfcontrol is internal and external factor. Internal factors that affect self-control is age. Increasing the age of a person, then the ability of one's self-control is also getting better. External factors that affect self-control is the family environment. Family environment, especially parents, determines how the ability to control oneself. A consistent attitude in applying discipline will be internalized by the child and become self-control for him.

The aspects of Averil's self-control are as follows (Gufron \& Risnawati, 2011, pp. 29-31), behavioral control, cognitive control, and decisional control. Behavioral control is the readiness or availability of a resp on that can directly affect or modify an unpleasant state. Manage Implementation. The ability to regulate the exercise is the ability of the individual to determine who is in control of the situation, himself or something outside himself. 
DOI:

Modifying Stimulus. The ability to regulate the stimulus is the ability to know how and when an unwanted stimulus is encountered.

Cognitive control is the ability of individuals to process undesirable information by interpreting, assessing or combining events within a cognitive framework as a psychological adaptation or to relieve pressure. Obtained information. Through information possessed by the individual about an unpleasant situation, an individual can anticipate the situation with various considerations. Perform an assessment. Conducting an assessment can be interpreted that an individual trying to assess and interpret a situation or event by considering the positive aspects are subjective.

Decisional control is the ability of a person to choose a result or an action based on something that is believed or approved. Anticipate events. Self-control in determining the choice of an opportunity, the freedom or the possibility of the individual to choose various possible actions. Interpreting events. Perform self-control based on the interpretation of an event that occurred

The level of self-control of each individual is different, there is a high and low self-control. The height and low self-control of a person depend on the ability to regulate and direct his behavior (Runtukahu, 2015). An individual tends to change his behavior according to the demands of the social situation which then gains situational clarity, is more flexible, warm and open, and seeks to facilitate social interaction (Gufron \& Risnawati, 2011, pp. 22-23). The importance of self-control is not only for normal people in general, but also important for children with special needs including children with hearing impairments.

Based on the above discussions, the purpose of this study was to determine the relationship of behavioral control, cognitive control, and decisional control in self-control for children with hearing impairments.

\section{Research Methodology}

In solving a problem, a research requires appropriate research methods. The research method used in this research is quantitative research method.The research was conducted at the Special School X for children with hearing impairments in Surakarta. The population in this study are children with hearing impairment in Surakarta. The sample in this study was students of secondary school and high school students in Schools X for children with hearing impairments in Surakarta numbered 30 people, consisting of 14 girls and 16 boys.

The technique of taking data in this research use scale. The use of scale because the data to be measured in the form of constructs or psychological concepts that can be known through the indicators of behavior that is translated in the form of statement items (Azwar, 2001). The instrument used in this research is a questionnaire of Likert scale consisting of 24 statements about selfcontrol and filled by respondents. The Likert scale is used to regulate the attitudes, opinions, and perceptions of a person or group of people about social phenomena called as research variables (Sugiyono, 2012, p.134).

\section{Results and Discussion}

\subsection{Results}

Self-control consists of several aspects: behavioral control, cognitive control, and decisional control. Self-control on the behavioral control aspect showed that 1 student got a very high score, that is 37 from the maximum score of 40. A total of 14 students got a high score, with score between 27-32.Students who scored were on behavioral control aspect, with the score between 23-26, as many as 11 students. The low score is owned by 3 students with scores between 1821. Meanwhile, the self-control score on the very low behavioral control aspect was obtained by 1 student with score 15 .

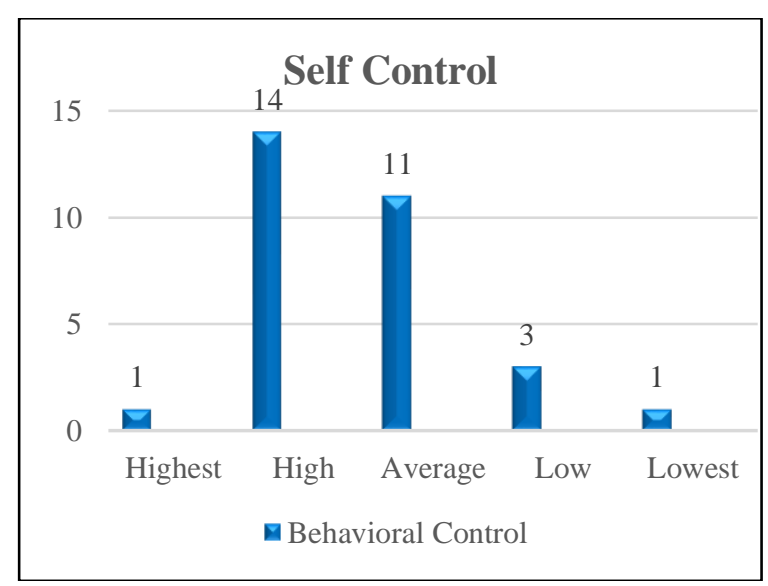

Fig 1. Self-Control Behavioral Control Cognitive, and Decisional Control in Self Control of Deaf Student. Indonesian Journal of Disability Studies (IJDS).2019: Vol. 6(1): PP 38-41. 


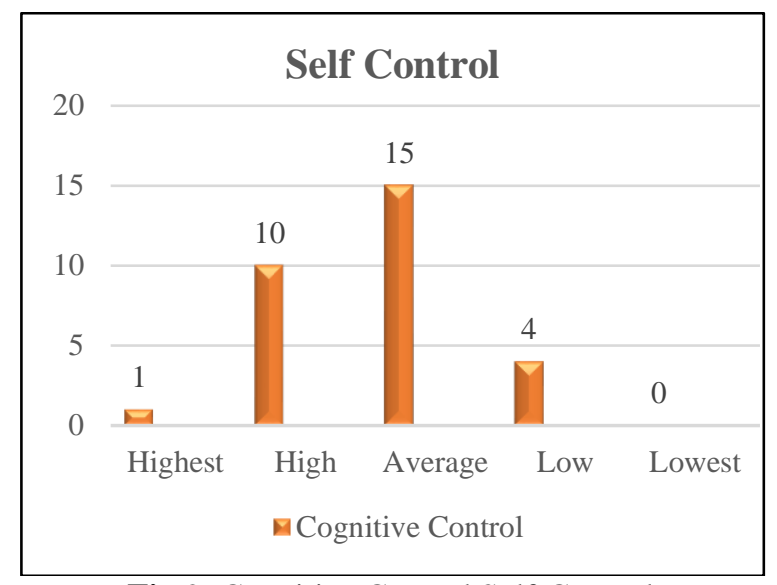

Fig 2. Cognitive Control Self-Control

In the aspect of cognitive control, student self-control with hearing loss showed the result of 1 student gets a very high score, that is 34 from the maximum score that is 40 . Student gets a high score as much as 10 students, with the score between 27-32. Scores are being gained by 15 students with scores between 22 26. Students who scored between 20-21 were 4 students and included low score category. Meanwhile, none of the students scored very low.

The third aspect of self-control is decisional control. The results of scores on this aspect can be seen in the graphic image below:

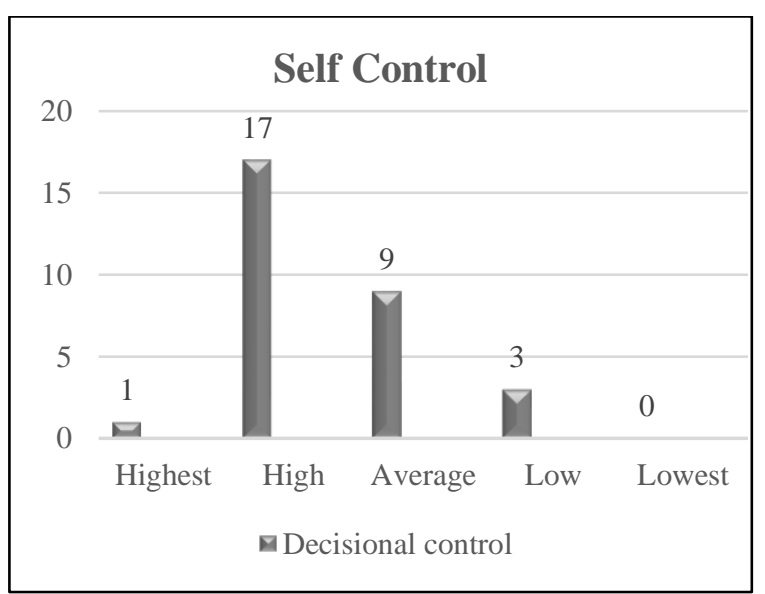

Fig 3. Self Control Decisional Control

In the decisional control aspect, it shows the result that 1 student get a very high score that is 33 from maximum score equal to 40 . A total of 17 students get a high score with the score between 27-31. Scores are being gained by 9 students with scores between 22-26. A total of 3 students a got low score with the score between 18-20. No students received very low scores.

Meanwhile, to compare the selfcontrol of various aspects, namely behavioral control, cognitive control, and decisional control can be seen in the graphic image below:

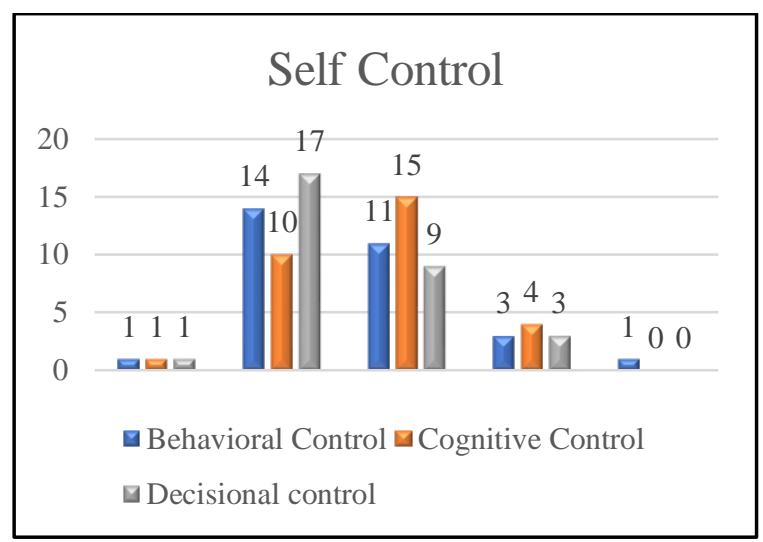

Fig 4. Self Control Behavioral Control, Cognitive Control, and Decisional Control

\subsection{Discussion}

The level of individual self-control varies, including children with special needs, especially children with hearing impairments, there is a high self-control and low. The height and low self-control of a person depend on the ability to regulate and direct his behavior (Runtukahu, 2015).

The highest level of self - control in children with hearing impairments is on the aspect of decisional control. In the decisional aspect control children with hearing impairment demonstrate their ability to choose a result or an action based on something they believe in or approve of. Decision-making decisions require a mature emotion to make decisions about the possible impacts of their decisions. This is in accordance with research conducted by Pradina (2017), that emotional maturity is a relative condition that shows the degree to which the individual is able to use the potential that is in him in the course of progress and strive to achieve maturity itself.

Behavioral control is the second level of self-control in children with hearing impairments. Behavioral control is the ability to influence or modify an unpleasant situation by preventing or avoiding the situation. For example, the child will prevent or avoid the occurrence of fights with not easy emotions, 
positive thinking, and not easily offended by the treatment of his friend.

Self-control measures on behavioral control aspects are formed by manipulating internal and external variables that affect behavior (Rahmawati, 2013). Self-control involves choosing intentionally; the choice between two conflicting behaviors and one behavior offers another long-term reward; and manipulates the stimulus so that one behavior is less likely to be elected (Skinner, 1996).

Meanwhile, the lowest level of selfcontrol in children with hearing impairments is cognitive control. Children with hearing impairment are less able to interpret, assess and combine an event in a cognitive context to reduce the negative impact of an event. This is in accordance with research conducted by Aringsun and Pratiwi (2014), that when a person is able to change his way of thinking and belief, then they will become better able to develop themselves and achieve what is expected optimally.

\section{Conclusion}

Based on the above discussions, it can be concluded that the level of student self-control with the highest hearing impairments on the aspects of decisional control, then the second level of behavioral aspects of control. Meanwhile, the degree of selfcontrol cognitive control is the lowest level of student self-control with hearing impairments.

\section{References}

Hijriah, A. (2014). Hubungan antara Self Control (Kontrol Diri) dan Social Interest (Interaksi Sosial) dengan Perilaku Sosial mahasiswa Jurusan Pendidikan Fisika Fakultas Tarbiyah dan Keguruan UIN Alauddin Makassar. Pp. 21-22

Riswandi, P. (2015). Pengaruh Pengendalian Diri dan Perilaku Belajar terhadap Tingkat emahaman Pengantar Akuntansi: Studi empiris pada Mahasiswa Program Studi Akuntansi Fakultas Ekonomi Universitas Prof. Hazairin
SH Kota Bengkulu. Ekombics Review. pp. 6472

Hurlock, E.B. (1990). Psikologi Perkembangan: Suatu Pendekatan Sepanjang Rentang Kehidupan (edisi kelima). Jakarta: Erlangga

Papalia, D.E., Olds, S.W., \& Feldman, R.D. (2004). Human Development (9th edition). USA: McGraw Hill

Gufron, M.N., \& Risnawati, S.R. (2011). Teori-teori Psikologi. Yogyakarta: Ar-Ruzz Media

Runtukahu, G.C., Sinolungan, J., \& Opod, H. (2015). Hubungan Kontrol Diri dengan Perilaku Merokok Kalangan Remaja di SMKN 1 Bitung. Jurnal e-Biomedik (eBm). Vol 3, No.1, JanuariApril 2015, pp. 84-92

Azwar, S. (2001). Metode Penelitian. Yogyakarta: Pustaka Pelajar

Sugiyono. (2012). Metode Psenelitian Pendidikan. Bandung: Alfabeta

Pradina, T. (2017). Hubungan antara Pengendalian Diri (Self Control) dengan Kemtangan Emosi Siswa Kelas XI di SMK Pelayaran Hang Tuah Kediri Tahun Ajaran 2016/2017. Artikel Skripsi Universitas Nusantara PGRI Kediri. 12.1.01.01.0029. pp. 1-8

Rahmawati, A. (2013). Hubungan antara Pengendalian Diri dengan Perilaku Membolos pada Siswa. E-Journal Universitas Muhammadiyah Surakarta

Skinner, B. F. (1996). Science and Human Behaviour. New York: McMillan

Ariningsun, A., \& Pratiwi, T. I. (2014). Penerapan Konseling Kelompok Rasional Emotif Perilaku untuk Meningkatkan Pengendalian Diri Siswa Kelas VIII SMP Negeri 4 Pnggul Trenggalek. E-Journal Universitas Negeri Surabaya. pp. 561-572. 